\title{
DETERMINANT FACTORS TOWARDS THE COMPETITIVENESS OF PINEAPPLE AGROINDUSTRY IN PANGKALPINANG
}

\author{
Miranty Dhea Putri ${ }^{1{ }^{1 *},}$ Yudi Sapta Pranoto ${ }^{1}$, Fournita Agustina ${ }^{1}$ \\ ${ }^{1}$ (Agribusiness, University of Bangka Belitung, Indonesia) \\ *corresponding author: midhepu@gmail.com
}

\begin{abstract}
This study aimed to analyze the determinant factors of competitiveness of agroindustry Pineapple in Pangkalpinang and to analyze the relationship between components in these factors in favor of agroindustry cluster growth pineapple. The data was collected in September 2016 until the month of March 2017 in Pangkalpinang. The method used is survey method. The number of respondents used in the study are 47 responden. The analytical method used is descriptive analysis, Delphi techniques, and the porter's diamond model analysis. The results of this study show that the primary determinant factors in the competitiveness of pineapple agroindustry in Pangkalpinang are the role of government factor and the opportunity factor. While the factors that have average influence to the pineapple agroindustry are strategy, structure and competition factors, demand factors, and supported factors of agroindustries. The linkage between the main components is not sinergy yet, because there is only one of six pairs of that supporting the development of agroindustry cluster. The conditions factor and supported agroindustry factors foster the existence of agroindustry. While the components of other factors, such as collaboration of agroindustry and universities to support technology and management, need to be improved in order to support the formation of pineapple agro-industrial cluster.
\end{abstract}

Keywords: competitiveness, pineapple agroindustrial

\section{INTRODUCTION}

Globalization and free trade has led to the rapid changes and unavoidable impact on the national and international economy. This implies increasing competition in various sectors, especially the industrial sector.

The competitiveness of industries in Indonesia did not show a significant progress in global competitiveness for the last period. Based on the Global Competitiveness Index (GCI), the World Economic Forum (WEF) shows that the position of Indonesia was ranked 37 out of 140 countries in the period 2015-2016. It showed actually decreasing competitivenes because the previous position of Indonesia was ranked 34 of 144 countries in period 2014-2015. While in the period of 2013-2014, Indonesia was ranked 38 th out of 144 countries and was even ranks 50 out of 144 countries in the period 2012-2013.

One sector in Indonesia focusing on development is agricultural sector and agroindustry. Agroindustry requires increased capacity of production for gainning competitiveness, one of them with a form of industrial clusters (Brenner, 1994). Agriculturebased industry clusters (agro-industry) is an approach that can be applied in order to promote agro-industry. That seeks to optimize the development and improvement of its competitiveness through the concept of linkage of agricultural production activities from upstream to downstream in achieving a competitive advantage globally. The cluster approach is intended to be a solution for improving the competitiveness of the leading commodity in a region.

Agricultural commodities in the regions need special attention in its development, in particular through the agroindustrial activity. One of horticultural crops that have good prospects for the development of agroindustry is the pineapple plant. Pineapple is a leading commodity in Pangkalpinang with the highest production per year when compared to six other districts in the province of Bangka Belitung. However, the agroindustry still needs to actively be built to increase the competitive capabilities to the industry.

This study examines the problems of pineapple agroindustry and analyzes a modeling to agro- 
industrial cluster of pineapple as one of the efforts to develop agroindustry in Pangkalpinang. Then, it will result in increasing global competitiveness in the future. The presence of agro-industrial cluster pineapple is expected to stimulate the commoditybased industries development of pineapple in Pangkalpinang.

\section{RESEARCH METHODS}

The research was conducted in Pangkalpinang, which is the largest pineapple producer in Bangka Belitung Province, Indonesia. The data collected were in September 2016 to March 2017. This study used a survey method. Respondents used were 47 respondents. The data were processed by descriptive qualitative using Delphi technique and Porter diamond analysis.

\section{RESULTS AND DISCUSSION}

\section{A. Competitiveness of Pineapple Agroindustry in Pangkalpinang}

In this study, the competitiveness factors of pineapple agroindustry in Pangkalpinang are determined by Diamond Porter's model. Furthermore, Delphi technique, which is evaluating competitiveness of agroindustry based on the assessment of all the expert respondents, is used for generating information of the priority factors affecting competitiveness of pineapple agroindustry in Pangkalpinang. There are five factors discussed in this study, namely the conditions; demand; strategy, structure and rivalry; related and supporting industries; the role of government; and opportunities. Those factors then be explained as follows:

\section{Conditions factor}

The condition factor indicates the position of a cluster as factors of production, which is the input needed to compete the others in the industry. Factors that influence the conditions of pineapple agroindustry competitiveness are natural resources, human resources, capital resources, production technology, and the location of clusters. To measure each of these dimensions, some indicator variables were used.

Based on the analysis, condition factors influenced of 18.21 per cent on the pineapple agroindustry competitiveness in Pangkalpinang. The results from the Delphi technique showed that all experts gave the information provided in the table regarding the factors determining the pineapple agroindustry competitiveness.

Table 1. Rate of conditions factors for Pineapple Agroindustry Cluster Formation, 2017

\begin{tabular}{|c|c|c|c|c|}
\hline No & Indicator Variables & Values & Weight & Score \\
\hline 1 & $\begin{array}{l}\text { Labors have the skills } \\
\text { required in company }\end{array}$ & 3 & 0.091 & 0.328 \\
\hline 2 & $\begin{array}{l}\text { Labors are able to produce } \\
\text { products in accordance } \\
\text { with the target of company }\end{array}$ & 4 & 0.083 & 0.301 \\
\hline 3 & $\begin{array}{l}\text { The raw material is } \\
\text { available in sufficient } \\
\text { quantities and easily } \\
\text { obtained }\end{array}$ & 3 & 0.087 & 0.297 \\
\hline 4 & $\begin{array}{l}\text { The quality of the raw } \\
\text { materials in accordance } \\
\text { with the demands and } \\
\text { tastes of consumers }\end{array}$ & 4 & 0.079 & 0.287 \\
\hline 5 & $\begin{array}{l}\text { Disclosure suppliers in } \\
\text { accepting input from } \\
\text { employers of pineapple } \\
\text { agroindustry }\end{array}$ & 4 & 0.076 & 0.273 \\
\hline 6 & $\begin{array}{l}\text { The timely delivery of raw } \\
\text { materials by suppliers }\end{array}$ & 3 & 0.079 & 0.271 \\
\hline 7 & $\begin{array}{l}\text { Current cluster layout of } \\
\text { the parties concerned is } \\
\text { strategic (the wholesale } \\
\text { market and the center of } \\
\text { the crowd) }\end{array}$ & 3 & 0.076 & 0.258 \\
\hline 8 & $\begin{array}{l}\text { Their training or } \\
\text { apprenticeship programs to } \\
\text { improve the skills of } \\
\text { labors }\end{array}$ & 4 & 0.068 & 0.246 \\
\hline 9 & $\begin{array}{l}\text { The price of the raw } \\
\text { materials used affordable }\end{array}$ & 3 & 0.072 & 0.245 \\
\hline 10 & $\begin{array}{l}\text { Factors capital is not a } \\
\text { constraint in the } \\
\text { development of enterprises }\end{array}$ & 1 & 0.087 & 0.209 \\
\hline 11 & $\begin{array}{l}\text { Utilization of the loan } \\
\text { system by third parties } \\
\text { (banks, cooperatives, and } \\
\text { other financial institutions) } \\
\text { to increase its business }\end{array}$ & 2 & 0.068 & 0.205 \\
\hline 12 & $\begin{array}{l}\text { Labor easily } r \text { obtained } \\
\text { because they come from } \\
\text { around the } \\
\text { location }\end{array}$ & 3 & 0.057 & 0.193 \\
\hline 13 & $\begin{array}{l}\text { Number of tools and } \\
\text { production machines used } \\
\text { are adequate }\end{array}$ & 1 & 0.072 & 0.158 \\
\hline
\end{tabular}

Table 1 shows that the total score obtained is 3.278, where it represents that the pineapple agroindustry based on condition factor has a "strong influence" in the development of pineapple agroindustry in Pangkalpinang.

The three indicator variables with the highest scores are labors that have skills as required, labors that are able to produce products in accordance with the target company, and the raw materials 
available in sufficient quantity and easy to obtain. Score each of the above variables, respectively, are $0.328,0.301$, and 0.297 .

Efforts to improve the quality of labor is a necessary condition. Considering labor and the environment of it as a dynamic socio-economic process are abviously complex. It requires skilled human resources to fill the labor market as expressed in RPJMD Pangkalpinang Year 20132018. One of the indicators to see the quality of labor is the ratio of graduates of $\mathrm{S} 1$ and $\mathrm{S} 2$. The ratio of graduates as bachelor and master in Pangkalpinang tends to increase by 3.16 percent per year. The significant increase was bachelor degree level. Bangka Belitung province and community considering the dynamic of thesociety and the economic activities require increasing the number of universities.

This suggests that the potential of available labor in Pangkapinang City is large enough to support the agroindustry cluster growth pineapple in Pangkalpinang. Potential human resources coming from university such as graduate as bachelor degree is important to run agroindustry well through their skill in applying the appropriate production techniques based on science, do business management, and implementing business development strategies in the agroindustry.

Currently, fresh pineapple supply mostly is coming from the Tua Tunu Sub-district. The raw materials for agroindustry is still be able to meet the demand. It is because the pineapple processing industry (agroindustry) is still relatively small. In fact, the supply of pineapple from Tua Tunu Subdistrict is more than the ability of agroindustri to absorb the pineapple supply; therefore, increasing economic of scale or increasing number of agroindustry is still possible. Therefore, nowadays farmers should struggle to build good relationship not only to agroindustri but also to other markets in order to avoid the lower prices due to over supply of pineapple in the market.

To build an agroindustrial clusters, quality, timeliness of delivery by suppliers of raw materials and the price of raw materials need to be managed properly. The quality of the raw materials will affect the output of the product. The best products need the best raw material as well. Moreover, the timely delivery of raw materials will ensure the product could be produced continuously without constrained the supply of raw materials.

Pineapple as raw material for agroindustry can be obtained at the lower price if the employer agroindustry build a linkage to the farmers in Tua
Tunu Sub-district as suppliers of pineapples. This will reduce production costs and increase revenue of agro-industries.

This is an opportunity for agroindstry to maintaining their production continuously through the mutual benefit cooperation between agroindustry and the farmers as the suplier of pineapple. Overcoming coordination problem is the first concern in developing pineapple agroindustry in Pangkalpinang, Bangka Belitung.

The supply of pineapple farming is one of supported factor for developing cluster agroindustry. Tua Tunu area is the center of pineapple production in Pangkalpinang. Another important point is that the soil of Tua Tunu has greatly support of pineapple production including the $\mathrm{pH}$ soil and climatic conditions. Soil conditions in this Tua Tunu Sub-district has an average $\mathrm{pH}$ below 5 which fits planted horticulture such as pineapple. In addition, the climate of the area Tua Tunu classified as type A, which is tropical wet with rain variation between 6.2 to $337.9 \mathrm{~mm}$ per month. Pineapple plants can grow optimally on wet or dry climatic conditions, both climate types A, B, $\mathrm{C}$ and $\mathrm{D}, \mathrm{E}, \mathrm{F}$. In general, this pineapple plants tolerant to drought and suitable to be planted on almost all types of land used for agriculture.

\section{Demand Factor}

Demand factor influence 16.46 percent in the competitiveness of pineapple agroindustry in Pangkalpinang. This factor has a total score of 2.964. This shows that demand factors have a "moderate impact" on the competitiveness of agropineapple in Pangkalpinang. The demand factor based assessment indicator variables are presented in the following table.

Based on Table 2, the three sequence indicator variable demand factors with the highest scores were high local market demand, market information greatly affect the production of agropineapple, and high market demand outside the region with a score of $0.567,0.484$, and 0.463 , respectively. The demand factors influence agroindustrial cluster formation pineapple currently in the classification of moderate rate because the businesses still feel independent and able to meet the market demand alone; even though, there is no mechanism of how the pineapple agroindustrial clusters supply the market. Market demand both locally and outside the region can still be handled well. 
The current condition is that the local market demand for products processed pineapple is not quite high due to lack of network marketing and promotion by agroindustry entrepreneurs. Those make the products are less attractive to consumers.

Table 2. Rate of demand factor on competitiveness of Agroindustry Pineapple Year 2017

\begin{tabular}{|c|c|c|c|c|}
\hline No & Indicator Variables & Value & Weight & Score \\
\hline 1 & $\begin{array}{l}\text { High demand for the } \\
\text { local market }\end{array}$ & 3 & 0.167 & 0.567 \\
\hline 2 & $\begin{array}{l}\text { Market information } \\
\text { greatly affect the } \\
\text { production of agro- } \\
\text { pineapple }\end{array}$ & 3 & 0.151 & 0.484 \\
\hline 3 & $\begin{array}{l}\text { Demand for high } \\
\text { outdoor market area }\end{array}$ & 3 & 0.136 & 0.463 \\
\hline 4 & $\begin{array}{l}\text { The share of products } \\
\text { is certain so it is not } \\
\text { difficult anymore to } \\
\text { find consumers }\end{array}$ & 3 & 0.143 & 0.460 \\
\hline 5 & $\begin{array}{l}\text { Cluster is able to } \\
\text { stimulate new markets } \\
\text { for processed } \\
\text { pineapple products } \\
\text { produced by } \\
\text { improving the quality } \\
\text { and innovation }\end{array}$ & 3 & 0.143 & 0.345 \\
\hline 6 & $\begin{array}{l}\text { Every year a } \\
\text { significant increase } \\
\text { over the local demand } \\
\text { for refined products } \\
\text { pineapple }\end{array}$ & 2 & 0.136 & 0.327 \\
\hline 7 & $\begin{array}{l}\text { Marketing chain are } \\
\text { generally short and } \\
\text { have been initiated } \\
\text { long ago }\end{array}$ & 3 & 0.121 & 0.315 \\
\hline & TOTAL & & 1.000 & 2.964 \\
\hline
\end{tabular}

The promotional activities are currently carried out only through the exhibition of products and orally. Promotion is the important option of introducing agroindutries products to prospective customers. Promotion will be more effective if done in various ways such as through social media, print media and electronic media locally through advertising. Thus, the product becomes known and attractive to potential consumers.

The demand of the products from outside the regionare very few because the marketing of products processed pineapple from Pangkalpinang are not yet widely spread. Actual market information is needed in the planning process and continuity of agro-industrial production as well.

The promotion as important factor of introducing the product is not been fully carried-out because the agro-pineapple in the research area is still relatively young. There is no market research conducted to get information the consumers' preference.

As stated in Pineapple Outlook (2015), potential exports of pineapple in Indonesia is actually quite high, but the role of Indonesia as a producer and exporter of fresh pineapples is still low. The problems are related to quality and food safety. Those are the major problems causing less contribution of fresh Indonesia pineapple production in international trade. However, Indonesia has experience in export of canned pineapple (CIC 2000, Hadi 2001). The largest exporter Great Giant Pineapple Company in Lampung is listed as the third cocktail exporter in the world.

Through pineapple agroindustry cluster, the ultimate goal is to meet consumer demand to the level of the world by producing high quality refined products and innovative pineapple products. Short marketing channels are also important in stregthening marketing efficiency of processed pineapple products.

3. Factors strategy, structure and competition in influencing competitiveness of pineapple agroindustry

Factors strategy, structure, and competition affect 14.42 percent in the competitiveness of agropineapple in Pangkalpinang. This factor has a total score of 2,596. Where this shows that the strategy, structure and rivalry have a "moderate impact" on the competitiveness of agro-pineapple in Pangkalpinang. The results of the factor assessment strategy, structure and competition based on indicator variables are presented in the following table.

Based on Table 3, three indicator variables that have the high scores are their internal networks or cooperation among similar industries, performing internal network with the upstream as suppliers of raw materials, auxiliary materials, and the means of production, and there is an internal network between actors such as agroindustry with downstream distributors, dealers, and consumers. Score each successive indicators are $0.477,0.461$, and 0.461 , respectively. 
Table 3. Variable Rate of strategy, structure and competition in influencing competitiveness of pineapple agroindustry, 2017

\begin{tabular}{|c|c|c|c|c|}
\hline No & Indicator Variables & Value & Weight & Score \\
\hline 1 & $\begin{array}{l}\text { Their internal networks } \\
\text { or cooperation among } \\
\text { similar industries }\end{array}$ & 3 & 0.159 & 0.477 \\
\hline 2 & $\begin{array}{l}\text { Agroindustry perform } \\
\text { internal network with the } \\
\text { upstream as suppliers of } \\
\text { raw materials, auxiliary } \\
\text { materials, and means of } \\
\text { production }\end{array}$ & 3 & 0.178 & 0.461 \\
\hline 3 & $\begin{array}{l}\text { There is an internal } \\
\text { network between actors } \\
\text { such as agroindustry with } \\
\text { downstream distributors, } \\
\text { agents, and consumers }\end{array}$ & 3 & 0.177 & 0.461 \\
\hline 4 & $\begin{array}{l}\text { Financial management } \\
\text { has done well, there are } \\
\text { financial records }\end{array}$ & 2 & 0.177 & 0.426 \\
\hline 5 & $\begin{array}{l}\text { Business management } \\
\text { has been good to do the } \\
\text { division of labor }\end{array}$ & 3 & 0.149 & 0.389 \\
\hline 6 & $\begin{array}{l}\text { Intense competition } \\
\text { among industries }\end{array}$ & 2 & 0.159 & 0.381 \\
\hline & TOTAL & & 1.000 & 2.596 \\
\hline
\end{tabular}

The important aspect should be taken as serious effort for developing comptitiveness is strengthening a good partnership in the aspect of production among similar agroindustries in Pangkalpinang, which are largely been guided or facilitated by the local government. The increasing production scale will gain more competitiveness than lower production scale of each individual producers playing individually.

In the provision of inputs, agroindustry has not cooperated with related parties yet. All inputs obtained from the market with high prices because it has been through the relatively long marketing channel. In fact, there is an option to establish cooperation with input suppliers in order to be able purchasing input in the lower price. This alternative can be reached if they are in the agro-industrial cluster mechanism. Cluster of pineapple agroindustry through cooperation in the marketing of pineapple products is strategic planning to be developt in Pangkalpinang.

\section{Related and Supporting Industries Factor}

Supported factors contribute 15.31 percent in the competitiveness of agro-pineapple in Pangkalpinang. This factor has a total score of 2.757. Where it shows that factors related and supporting industries have "moderate impact" on the competitiveness of agro-pineapple in
Pangkalpinang. The results of the assessment of supported factors agroindustries based on indicator variables are presented in the following table.

Table 4. Variable rate indicator of supported factors influencing competitiveness of agro industry pineapple in Pangkalpinang 2017

\begin{tabular}{lllll}
\hline No & \multicolumn{1}{c}{ Indicator Variables } & Value & Weight & Score \\
\hline 1 & $\begin{array}{l}\text { The local community } \\
\text { strongly supports the } \\
\text { development of agro- } \\
\text { industries through cluster } \\
\text { growth so as create a } \\
\text { symbiotic mutualism, }\end{array}$ & & & \\
agro easily obtain labor \\
resources.
\end{tabular}

Based on Table 4, three indicators that have the highest score are (1) the support of local community will strengthen the development of agroindustry, (2) the involvement of government or agencies involved in mentoring, marketing, and financing of agroindustry, and (3) cooperation with universities and research institutes are imperative for developing agro-industries. Score each successive indicator variable is equal to 0.559 , 0.413 , and 0.316 . 
Pineapple agroindustry cluster requires huge support from the local community. Based on the results of the study, most respondents do not know the term of agroindustrial cluster exactly; however, the respondents expect that the strategy for increasing coordination among agents in the indutsry are important factor for developing competitiveness. Great support from the local community is expected to facilitate agroindustrial obtaining skilled human resources as labor in the industry. Growth of agroindustry cluster can be a source of jobs for local people and increase the industrial scale.

Government or related agencies currently providing support in the form of training and mentoring, but there is no support access to finance agro-industries. The roles of government in fostering agroindustries include the provision of technical training of production and financial management. The greater support from the government or related agencies in terms of coaching, marketing network, and access to capital to develop agro-industries will accelerate the groth of the agroindustries.

Currently, cooperation with universities and research institutions has not been developed yet. Universities and research institutions are central to the creation of innovation clusters that can support the development of agroindustries. Financial management in the form of financial recording industry has to be conducted by all agroindustries. The facts are they do not record cash flow of the firm in detail and do not always do the recording at a time of production expenses and the revenue generated. In addition, there is no specialization and division of labor in the agroindustry. This is because the production process is small-scale, so the division of labor in particular has not been necessary. Moreover, competition among similar agroindustries are not clearly visible.

\section{Factors Role of Government}

The role of government contributes 18.09 percent the competitiveness of agro-pineapple in Pangkalpinang. This factor has a total score of 3.257. This shows that the role of government has a "strong influence" on the competitiveness of agropineapple in Pangkalpinang. The results of the assessment factors of the government roles based on indicator variables are presented in following table.
Table 5. Government roles in Agro Industry Pineapple Competitiveness Year, 2017

\begin{tabular}{clccc}
\hline No & Indicator Variables & Value & Weight & Score \\
\hline 1 & $\begin{array}{l}\text { Government policy in } \\
\text { the agroindustry } \\
\text { cluster development } \\
\text { pineapple }\end{array}$ & 4 & 0,262 & 0,945 \\
2 & $\begin{array}{l}\text { The government's role } \\
\text { in supporting } \\
\text { infrastructure } \\
\text { The role of } \\
\text { government in } \\
\text { training, counseling, } \\
\text { and guidance } \\
\text { technology }\end{array}$ & 3 & 0,262 & 0,840 \\
4 & $\begin{array}{l}\text { The role of } \\
\text { government in } \\
\text { shaping domestic } \\
\text { demand }\end{array}$ & 3 & 0,238 & 0,760 \\
& & & & \\
TOTAL & 1,000 & 3,257 \\
\hline
\end{tabular}

Based on Table 5, two indicator variables that have the highest score are government policies in the development of pineapple agroindustrial cluster and role of government in supporting infrastructure. Score each successive indicator variable is equal to 0.945 , and 0.840 , respectively.

The government's roles as a facilitator, regulator and motivator in improving the competitiveness of agro-pineapple in Pangkalpinang are pivotal. Some actions have been manifested, such as providing training in pineapple processing into derived products, coaching, and supporting financial evaluation for agroindustries.

In the agro-industrial cluster growth requires greater support from relevant government policies related to the agro-industrial clusters. One of them is to facilitate liaison between farmers and agroindustries to harmonize the goals, standards and regulations among the agents. In addition, the role of government in shaping the local demand through the provision of market access and provide support in improving the appearance of refined products produced agroindustries in Pangkalpinang.

\section{The Opportunity Factor}

Opportunities of agroindustries influence 17.48 percent in the competitiveness of agro-pineapple in Pangkalpinang. This factor has a total score of 3.147. This shows that the role of opportunity has "strong influence" on the competitiveness of agropineapple in Pangkalpinang. The factors assessment results based indicator variables are presented in Table 6 below. 
Table 6. Variable rate indicator opportunities factors influencing competitiveness of agroindustry pineapple, 2017

\begin{tabular}{clccc}
\hline No & Indicator Variables & Value & Weight & Score \\
\hline 1 & $\begin{array}{l}\text { Still the market } \\
\text { opportunities in both the } \\
\text { district and provincial }\end{array}$ & 3 & 0.250 & 0.800 \\
2 & $\begin{array}{l}\text { Still the market } \\
\text { opportunities at national } \\
\text { level }\end{array}$ & 3 & 0.250 & 0.800 \\
3 & $\begin{array}{l}\text { The entrepreneurial spirit } \\
\text { of agroindustry actors } \\
\text { pineapple } \\
4\end{array}$ & 2 & 0.262 & 0.787 \\
$\begin{array}{l}\text { The new discoveries in } \\
\text { the field of production of } \\
\text { fresh pineapple and } \\
\text { pineapple processed } \\
\text { TOTAL }\end{array}$ & 3 & 0.237 & 0.760 \\
\hline
\end{tabular}

Based on Table 6, two indicator variables that have the highest score are (1) a good market opportunities in the district and provincial levels and (2) there are still a good market opportunities at the national level. Score of those indicatorsare the same, which are 0.800 . Market opportunities on a regional basis are caused by the increasing consumption of processed pineapple products along with increasing awareness of the importance of health in consuming healty food. Moreover, the availability of processed pineapple products in Pangkalpinang is potential to become one of the many popular consumer products from Lampung.

Increasing population and awareness to consume fruits is expected to increase consumption of pineapple products. In this case, increasing economic of scale of agroidutries is necessary condition as well as strengtening the supply chain of the products.

The production is not only to meet the demand for fresh pineapple, but also to increase the value added to processed products of pineapple. Indonesia pineapple has not been managed optimally because the pienapple production highly competes with other horticultural products in resources used. Generally, several characteristics inherent in the development of pineapple are that unplanned farmers cultivation of the crop resulting in unbalanced supply and demand all the time and that also causes the fuctuation of price as well (Lopez et al., 2014).

Similar to Manasis (2010), the results of the analysis identifying competitiveness of agropineapple in Pangkalpinang can be mapped in the model Diamond Porter as presented in Figure 1. It can be concluded that the relationship between the main components is weak because there is only one of six pairs of mutually supportive components. The condition factor has supported growth of pineapple agroindustry cluster. Natural resources should be used optimally.

Pineapple supply will be strengthened if the pineapple cropping system is managed well, such as scheduling in planting. Furthermore, the product as continuous pineapple supply supporting the growth of the agroindustries.

Potential human resources are significant factor providing workforce needed to run agroindustries. Cluster growth at the same time will open employment opportunities for people in the study area. It is because along with the cluster, it will seek to expand its agroindustry in order to exploit the market. With a strong influence in determining the competitiveness of agro-industry, condition factor and opportunity factors support cluster growth for the future.

The government (in terms of policy and infrastructure) and supporting factors have a moderate influence in determining the competitiveness of agroindustry. The availability of technology and the government support have been existed and those will increase along with developing agroindustry cluster in Pangkalpinang.

While the two major components that need special attention in the effort of growing pineapple agroindustry clusters are demand factor, strategy, structure, and rivalry. The other important factor is creating co-operation in the form of partnerships between farmers as suppliers of raw materials pineapple and agroindustry. This is important because this will shorthen the market channel of pineapple and will minimize production costsof agroindustry.

The marketing aspect of processed pineapple products requires the strength of internal network in order to perform effective marketing network to deliver the product to consumers. Even though, the potential export of processed pineapple products is very high, the market served by the agroindustry is still limited to local consumers. Increased demand can be done by making innovations aimed at attracting customers and tailored to the tastes of consumers (product differentiation), define market segmentation, implement a cost advantage, as well as promoting broadly. 


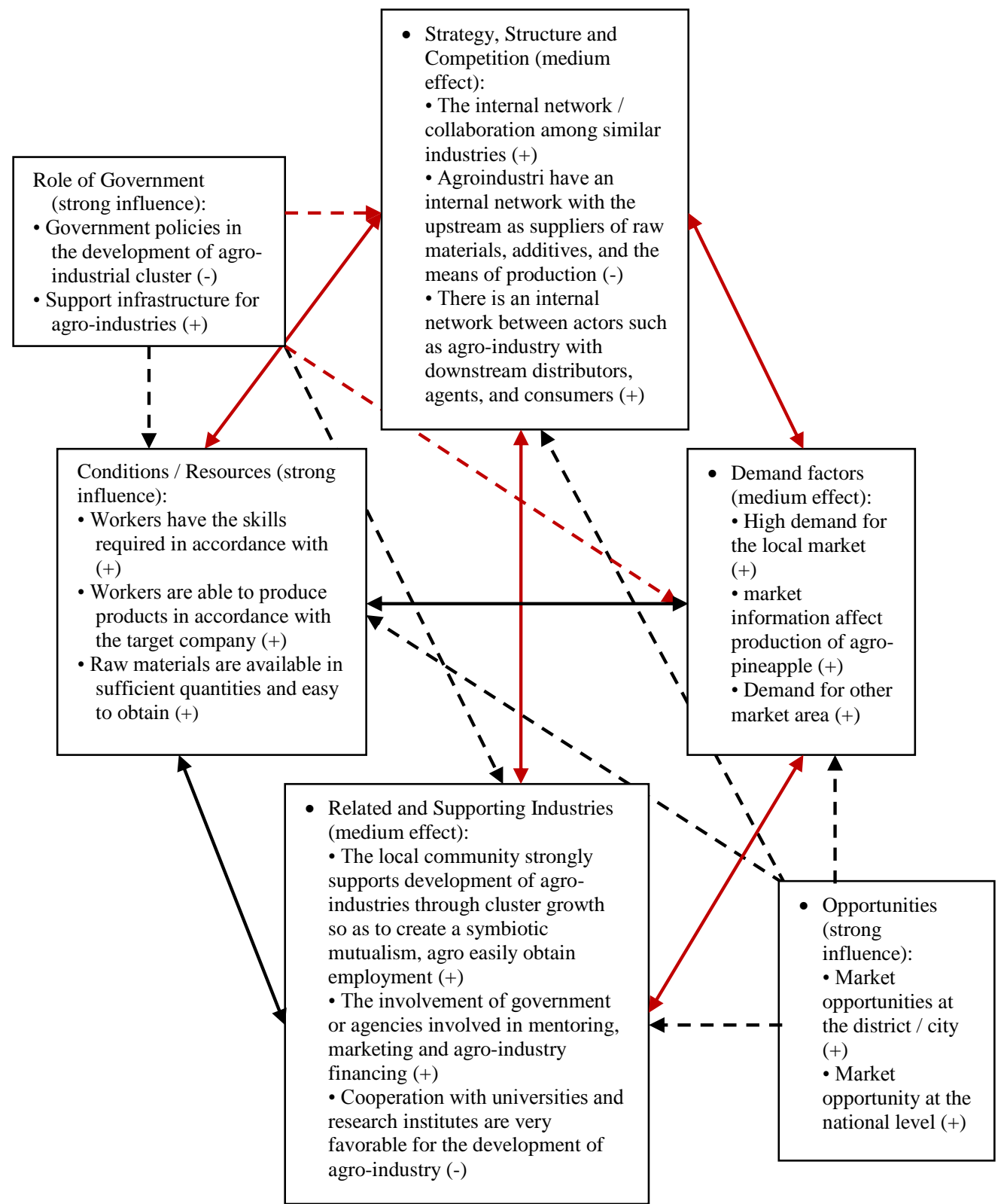

Notes:

$(+)=$ the indicator variables supporting the agro-industrial cluster growth pineapple

$(-)=$ the indicator variables that do not support cluster growth agro-pineapple

$\longleftrightarrow \quad$ Showing weak mutual support between the main components

Indicates mutually supportive linkages between the major components and support components

$\longleftrightarrow \quad$ Shows that the relationship among the main components do not mutually support agroindustry

$\rightarrow$ Shows that the relationship among the major components and supported component do not support agroindustry

Figure - 1. Diamond Porter competitiveness development of agro-pineapple in Pangkalpinang 
The important supporting components are the roles of government policy and the roles of opportunity to provide support for the establishment of agroindustrial competitiveness of pineapple. These factors can foster the agroindustry development if all stakeholders are working together and taking the roles for exploiting the existed opportunity.

\section{CONCLUSION}

The determinant factors strengthening the competitiveness of pineapple agroindustry are condition factor, the role of government, and the opportunity factor. While the factors that have average influence include strategy, structure and competition factor, demand factors, and supported factors of agroindustries. The linkage between the main components is not synergy because there is only one among six pairs support agroindustry. While the components of other factors need to be improved in order to support growth of pineapple agroindustry.

\section{REFERENCES}

Brenner, T. (2004). Local Industrial Cluster Existence, Emergence and Evolution. London and New York : Routledge, Taylor and Francis Group

CIC, (2000). Prospects of Canned Pineapple Industry and Marketing in Indonesia, PT. Carpricorn Indonesia. Consult Inc., Indonesia

Djamhari, C. (2006). Faktor-faktor yang mempengaruhi Perkembangan Sentra UKM Menjadi Klaster Dinamis. Jurnal Infokop, Nomor 29, Tahun XXII, hal 83-91.

Hadi, P.U. (2001). The Case Study of Canned Pineapple in Indonesia. Jakarta: Puspa Swara

Manasis G. (2010). Analysis of competitiveness of Greek's olive oil sector using Porter's Diamond Model. Journal of International Studies. 